\title{
Taxonomic study of Hypotrachyna subg. Everniastrum (Hale ex Sipman) Divakar, A.Crespo, Sipman, Elix \& Lumbsch (Ascomycota) from China
}

Xin Yu WANG

Yan Yun ZHANG

Key Laboratory for Plant Diversity and Biogeography of East Asia, Kunming Institute of Botany, CAS, Kunming, Yunnan 650201 (China)

wangxinyu@mail.kib.ac.cn

Dong LIU

Key Laboratory for Plant Diversity and Biogeography of East Asia, Kunming Institute of Botany, CAS, Kunming, Yunnan 650201 (China) and Korean Lichen Research Institute (KoLRI), Sunchon National University, Suncheon (Korea)

Li Juan LI

Key Laboratory for Plant Diversity and Biogeography of East Asia, Kunming Institute of Botany, CAS, Kunming, Yunnan 650201 (China) and Department of Botany and Molecular Evolution, Senckenberg Research Institute, 60325 Frankfurt am Main (Germany)

Mei Xia YANG

Key Laboratory for Plant Diversity and Biogeography of East Asia, Kunming Institute of Botany, CAS, Kunming, Yunnan 650201 (China) and Snow and Landscape Research (WSL),

Federal Institute for Forest, Zurich (Switzerland)

An Cheng YIN

Li Song WANG

Key Laboratory for Plant Diversity and Biogeography of East Asia, Kunming Institute of Botany, CAS, Kunming, Yunnan 650201 (China) wanglisong@mail.kib.ac.cn (corresponding author)

Wang X. Y., Zhang Y. Y., Liu D., Li L. J., Yang M. X., Yin A. C. \& Wang L. S. 2020. - Taxonomic study of Hypotrachyna subg. Everniastrum (Hale ex Sipman) Divakar, A.Crespo, Sipman, Elix \& Lumbsch (Ascomycota) from China. Cryptogamie, Mycologie 41 (12): 193-209. https://doi.org/10.5252/cryptogamie-mycologie2020v41a12. http://cryptogamie. com/mycologie/41/12

\section{ABSTRACT}

The taxonomy of Hypotrachyna subg. Everniastrum (Hale ex Sipman) Divakar, A.Crespo, Sipman, Elix \& Lumbsch from China is revised based on morphological, chemical and phylogenetic analyses. Four species new to science (Hypotrachyna corallifera Xin Y.Wang \& Li S. Wang, sp. nov., H. longicilia Xin Y.Wang \& Li S.Wang, sp. nov., H. puerensis Xin Y.Wang \& Li S. Wang, sp. nov., and H. yunnana Xin Y.Wang \& Li S.Wang, sp. nov.) and a new floristic record for one species (H. catawbiensis (Degel.) Divakar, A.Crespo, Sipman, Elix \& Lumbsch) in China are reported, and a total of fifteen species are 


KEY WORDS
New species,
phylogeny,
hidden diversity,
lichens,
Parmeliaceae,
China.

MOTS CLÉS

Nouvelles espèces,

phylogénie,

diversité cachée,

lichens,

Parmeliaceae,

Chine. confirmed, including all the species previously reported from China. Specimens of three species $(H$. cirrhata (Fr.) Divakar, A.Crespo, Sipman, Elix \& Lumbsch, H. nepalensis (Taylor) Divakar, A.Crespo, Sipman, Elix \& Lumbsch and H. vexans (Zahlbr. ex W.L.Culb. \& C.F.Culb.) Divakar, A.Crespo, Sipman, Elix \& Lumbsch) from the type localities are sequenced, providing fundamental molecular data for species delimitation. New chemical varieties are detected for $H$. diffractaica (Y.M.Jiang \& J.C.Wei) Divakar, A.Crespo, Sipman, Elix \& Lumbsch. Detailed descriptions and figures for the new species and a key to all known species from China are provided.

\section{RÉSUMÉ}

Étude taxonomique de Hypotrachyna subg. Everniastrum (Hale ex Sipman) Divakar, A.Crespo, Sipman, Elix \& Lumbsch (Ascomycota) de Chine.

La taxonomie de Hypotrachyna subg. Everniastrum (Hale ex Sipman) Divakar, A.Crespo, Sipman, Elix \& Lumbsch de Chine est révisée sur la base d'analyses morphologiques, chimiques et phylogénétiques. Quatre espèces nouvelles pour la science (Hypotrachyna corallifera Xin Y.Wang \& Li S.Wang, sp. nov., H. longicilia Xin Y.Wang \& Li S.Wang, sp. nov., H. puerensis Xin Y.Wang \& Li S.Wang, sp. nov., et $H$. yunnana Xin Y.Wang \& Li S.Wang, sp. nov.) et un nouveau signalement floristique pour une espèce (H. catawbiensis (Degel.) Divakar, A.Crespo, Sipman, Elix \& Lumbsch) en Chine sont signalés. Un total de quinze espèces est confirmé, y compris toutes les espèces précédemment signalées en Chine. Des spécimens provenant des localités types de trois espèces $(H$. cirrhata $(\mathrm{Fr}$.) Divakar, A.Crespo, Sipman, Elix \& Lumbsch, H. nepalensis (Taylor) Divakar, A.Crespo, Sipman, Elix \& Lumbsch et $H$. vexans (Zahlbr. ex W.L.Culb. \& C.F.Culb.) Divakar, A.Crespo, Sipman, Elix \& Lumbsch) sont séquencés, ce qui fournit des données moléculaires fondamentales pour la délimitation des espèces. De nouvelles variétés chimiques sont détectées pour $H$. diffractaica (Y.M.Jiang \& J.C.Wei) Divakar, A.Crespo, Sipman, Elix \& Lumbsch. Des descriptions et des figures détaillés pour les nouvelles espèces ainsi qu'une clé pour toutes les espèces connues de Chine sont fournis.

\section{INTRODUCTION}

The genus Everniastrum Hale ex Sipman, typified by E. cirrhatum (Fr.) Hale ex Sipman, was first segregated from the genus Parmelia Ach. as section Everniiformes by Hue (1898), characterized by narrow lobes with marginal cilia. In 1971, section Everniiformes was upgraded to Parmelia subg. Everniiformes by Hale \& Wirth (1971), including 16 species. In 1976, Hale transferred this subgenus into the new genus Everniastrum Hale, including 21 species (Hale 1976). Later, Sipman segregated Cetrariastrum Sipman from Everniastrum based on characters of the apothecia (Sipman 1980). One year later, Culbersons published a paper questioning the validity of this new genus and used Cetrariastrum as the correct name for Everniastrum (Culberson \& Culberson 1981). In 1986, Sipman re-evaluated the differences between these two genera and reinstated the genus Everniastrum with 27 species, and Cetrariastrum included three species (Sipman 1986). Since that time, the genus name Everniastrum has been widely accepted and used worldwide. A recent molecular study transferred this genus into a subgenus, Hypotrachyna subg. Everniastrum (Divakar et al. 2013), including c. 40 species.

Ten species of Everniastrum have been previously reported from China (Chen 2011; Chen et al. 2015), including five species originally described from China (Culberson \& Culberson 1981; Wei \& Jiang 1982; Chen et al. 1989; Jiang \& Wei 1989; Jiang \& Wei 1993), while H. lipidifera was excluded from subgenus Everniastrum and placed in the subgenus Cetrariastrum
(Divakar et al. 2013). After examination of a large number of samples, including type specimens and fresh specimens collected at the type localities, 15 species are recognized in this study, including four species new to science $(H$. corallifera Xin Y.Wang \& Li S.Wang, sp. nov., H. longicilia Xin Y.Wang \& Li S.Wang, sp. nov., H. puerensis Xin Y.Wang \& Li S.Wang, sp. nov., and H. yunnana Xin Y.Wang \& Li S.Wang, sp. nov.) and a new floristic record for one species (H. catawbiensis (Degel.) Divakar, A.Crespo, Sipman, Elix \& Lumbsch) in China. Detailed descriptions and figures for the new species are provided, together with a key to all known Chinese Everniastrum species.

\section{MATERIAL AND METHODS}

\section{MORPHOLOGY AND CHEMISTRY}

Approximately 1600 specimens at the Lichen Herbarium, Kunming Institute of Botany (KUN), were examined, and type material and related specimens were borrowed from the following herbaria: HMAS, TUR, US and W. Specimens were examined using standard microscopic techniques and hand-sectioned under a Nikon SMZ 745 T dissecting microscope. Anatomical descriptions are based on observations of these preparations under a Nikon Eclipse 50i microscope, and photographs were taken using a Nikon DS-Fi2 digital camera head. The sizes of the thallus, apothecia and lobes are based on measurements for each specimen and are presented as a range from the smallest to the largest value. 
TABLE 1. - Specimens used in the phylogenetic analysis of ITS sequences, with name $(H .=$ Hypotrachyna), locality, voucher and GenBank accession number. Newly obtained sequences are in bold face.

\begin{tabular}{|c|c|c|c|}
\hline Taxon & Locality & Voucher & Accession number \\
\hline $\begin{array}{l}\text { H. cirrhata (Fr.) Divakar, A.Crespo, Sipman, } \\
\text { Elix \& Lumbsch }\end{array}$ & $\begin{array}{l}\text { China, Xizang Prov., Jilong Co. } \\
\text { China, Xizang Prov., Jilong Co. } \\
\text { China, Xizang Prov., Jilong Co. } \\
\text { China, Xizang Prov., Jilong Co. } \\
\text { China, Xizang Prov., Jilong Co. } \\
\text { Nepal, Bagmati } \\
\text { Nepal, Bagmati } \\
\text { China, Xizang Prov., Jilong Co. } \\
\text { Nepal, Bagmati } \\
\text { China, Xizang Prov., Jilong Co. } \\
\text { Costa Rica, San Jose } \\
\text { Peru }\end{array}$ & $\begin{array}{l}\text { KUN 17-57613 } \\
\text { KUN 17-57632 } \\
\text { KUN 17-57734 } \\
\text { KUN 17-57607 } \\
\text { KUN 17-57718 } \\
\text { KUN 17-57305 } \\
\text { KUN 17-57318 } \\
\text { KUN 17-57808 } \\
\text { KUN 17-57253 } \\
\text { KUN 17-57617 } \\
\text { MAF-Lich } 7465 \\
\text { MAF 13976 }\end{array}$ & $\begin{array}{l}\text { MN335170 } \\
\text { MN335171 } \\
\text { MN335173 } \\
\text { MN335172 } \\
\text { MN335169 } \\
\text { MN335166 } \\
\text { MN335167 } \\
\text { MN335174 } \\
\text { MN335168 } \\
\text { MN335175 } \\
\text { AY611070 } \\
\text { DQ279487 }\end{array}$ \\
\hline $\begin{array}{l}\text { H. columbiensis (Zahlbr.) Divakar, A.Crespo, } \\
\text { Sipman, Elix \& Lumbsch }\end{array}$ & $\begin{array}{l}\text { Peru } \\
\text { Peru }\end{array}$ & $\begin{array}{l}\text { MAF } \\
\text { MAF(PY01) }\end{array}$ & $\begin{array}{l}\mathrm{KX} 254122 \\
\mathrm{KX} 254123\end{array}$ \\
\hline H. corallifera Xin Y.Wang \& Li S.Wang, sp. nov. & $\begin{array}{l}\text { China, Yunnan Prov., Shizong Co. } \\
\text { China, Yunnan Prov., Shizong Co. } \\
\text { China, Yunnan Prov., Shizong Co. } \\
\text { China, Taiwan Prov., Jiayi Co. }\end{array}$ & $\begin{array}{l}\text { KUN 14-47191 } \\
\text { KUN 14-47268 } \\
\text { KUN 14-47284 } \\
\text { KUN 15-49365 }\end{array}$ & $\begin{array}{l}\text { MN335178 } \\
\text { MN335179 } \\
\text { MN335177 } \\
\text { MN335176 } \\
\end{array}$ \\
\hline $\begin{array}{l}\text { H. dubitans (Sipman) Divakar, A.Crespo, Sipman, } \\
\text { Elix \& Lumbsch }\end{array}$ & Peru, Ancash & F(MAF-Lich 15621) & GQ919269 \\
\hline H. himalayana Divakar \& Kirika & $\begin{array}{l}\text { China } \\
\text { India }\end{array}$ & $\begin{array}{l}\text { MAF-10375 } \\
\text { MAF }\end{array}$ & $\begin{array}{l}\text { DQ279490 } \\
\text { KX254124 }\end{array}$ \\
\hline $\begin{array}{l}\text { H. kaernefeltii Divakar, A.Crespo, Sipman, } \\
\text { Elix \& Lumbsch }\end{array}$ & Peru, Ancash & MAF-Lich 15620 & GQ919270 \\
\hline H. longicilia Xin Y.Wang \& Li S.Wang, sp. nov. & $\begin{array}{l}\text { China, Taiwan Prov., Jiayi Co. } \\
\text { China, Taiwan Prov., Jiayi Co. } \\
\text { China, Taiwan Prov., Jiayi Co. } \\
\text { China, Taiwan Prov., Jiayi Co. } \\
\text { China, Taiwan Prov., Jiayi Co. }\end{array}$ & $\begin{array}{l}\text { KUN 15-49407 } \\
\text { KUN 15-49424 } \\
\text { KUN 15-49417 } \\
\text { KUN 15-49382 } \\
\text { KUN 15-49399 }\end{array}$ & $\begin{array}{l}\text { MN335183 } \\
\text { MN335184 } \\
\text { MN335180 } \\
\text { MN335181 } \\
\text { MN335182 }\end{array}$ \\
\hline $\begin{array}{l}\text { H. nepalensis (Taylor) Divakar, A.Crespo, Sipman, } \\
\text { Elix \& Lumbsch }\end{array}$ & $\begin{array}{l}\text { Nepal, Bagmati } \\
\text { China, Xizang Prov., Jilong Co. } \\
\text { China, Xizang Prov., Jilong Co. } \\
\text { Nepal, Bagmati } \\
\text { China, Xizang Prov., Jilong Co. }\end{array}$ & $\begin{array}{l}\text { KUN 17-57216 } \\
\text { KUN 17-57630 } \\
\text { KUN 17-57461 } \\
\text { KUN 17-57370 } \\
\text { KUN 17-57633 }\end{array}$ & $\begin{array}{l}\text { MN335185 } \\
\text { MN335189 } \\
\text { MN335188 } \\
\text { MN335186 } \\
\text { MN335187 }\end{array}$ \\
\hline H. puerensis Xin Y.Wang \& Li S.Wang, sp. nov. & $\begin{array}{l}\text { China, Yunnan Prov., Pu'er Ci. } \\
\text { China, Yunnan Prov., Pu'er Ci. } \\
\text { China, Yunnan Prov., Zhenyuan Co. }\end{array}$ & $\begin{array}{l}\text { KUN 13-41500 } \\
\text { KUN 13-41509 } \\
\text { KUN 13-38611 }\end{array}$ & $\begin{array}{l}\text { MN335192 } \\
\text { MN335190 } \\
\text { MN335191 }\end{array}$ \\
\hline $\begin{array}{l}\text { H. sorocheila (Vain.) Divakar, A.Crespo, Sipman, } \\
\text { Elix \& Lumbsch }\end{array}$ & $\begin{array}{l}\text { Columbia, Cundinamarca } \\
\text { New Zealand } \\
\text { Kenya, Western Province } \\
\text { Kenya, Western Province } \\
\text { Portugal, Madeira }\end{array}$ & $\begin{array}{l}\text { F } \\
\text { F, MAF-Lich } \\
\text { MAF } \\
\text { MAF }\end{array}$ & $\begin{array}{l}\text { KX254129 } \\
\text { KX254133 } \\
\text { JN943841 } \\
\text { KX254125 } \\
\text { KX341977 }\end{array}$ \\
\hline $\begin{array}{l}\text { H. subsorocheila (Y.M.Jiang \& J.C.Wei) Divakar, } \\
\text { A.Crespo, Sipman, Elix \& Lumbsch }\end{array}$ & $\begin{array}{l}\text { China, Taiwan Prov., Jiayi Co. } \\
\text { China, Taiwan Prov., Jiayi Co. }\end{array}$ & $\begin{array}{l}\text { KUN 15-49364 } \\
\text { KUN 15-49393 }\end{array}$ & $\begin{array}{l}\text { MN335194 } \\
\text { MN335193 }\end{array}$ \\
\hline $\begin{array}{l}\text { H. vexans (Zahlbr. ex W.L.Culb. \& C.F.Culb.) } \\
\text { Divakar, A.Crespo, Sipman, Elix \& Lumbsch }\end{array}$ & $\begin{array}{l}\text { China, Taiwan Prov., Jiayi Co. } \\
\text { China, Yunnan Prov., Deqin Co. } \\
\text { China, Yunnan Prov., Shizong Co. } \\
\text { China, Yunnan Prov., Pingbian Co. }\end{array}$ & $\begin{array}{l}\text { KUN 15-49391 } \\
\text { KUN 12-36365 } \\
\text { KUN 14-47283 } \\
\text { KUN 14-42527 }\end{array}$ & $\begin{array}{l}\text { MN335196 } \\
\text { MN335197 } \\
\text { MN335195 } \\
\text { MN335198 } \\
\end{array}$ \\
\hline H. yunnana Xin Y.Wang \& Li S.Wang, sp. nov. & $\begin{array}{l}\text { China, Yunnan Prov., Lijiang Ci. } \\
\text { China, Yunnan Prov., Nanjian Co. }\end{array}$ & $\begin{array}{l}\text { KUN 13-40919 } \\
\text { KUN 12-37635 }\end{array}$ & $\begin{array}{l}\text { MN335200 } \\
\text { MN335199 }\end{array}$ \\
\hline
\end{tabular}

Secondary metabolites of all the specimens were identified using spot tests and thin-layer chromatography (TLC) as described by White \& James (1985) and Orange et al. (2001). Solvent $\mathrm{C}$ (toluene: acetic acid $=85: 15$ ) was used for TLC analysis.

\section{PHYLOGENETIC ANALYSES}

Total DNA was extracted from small fragments of fresh thallus tips or apothecia following the protocol by Ekman (1999) using the
AxyPrep Multisource Genomic DNA Miniprep Kit. The nrDNA ITS region (ITS1-5.8S-ITS2) was amplified by PCR using the ITS1F (Gardes \& Bruns 1993) and ITS4 (White et al. 1990) primers. The conditions previously described by Arup (2002) were used for PCR. Specifically, $2 \mu \mathrm{L}$ of genomic DNA was added to the following mixture: $2 \mu \mathrm{L}$ of primer $(1 \mu \mathrm{L}$ of each primer in a $10 \mathrm{mM}$ solution), $12.5 \mu \mathrm{L}$ of $2 \times$ Taq PCR MasterMix (Aidlab) (containing Taq DNA polymerase: 0.1 unit $\mu \mathrm{L}, \mathrm{MgCl}_{2}: 4 \mathrm{mM}$, 
and dNTPs: $0.4 \mathrm{mM}$ ) and $8.5 \mu \mathrm{L}$ of $\mathrm{dH}_{2} \mathrm{O}$ for a total volume of $25 \mu \mathrm{L}$. Amplifications were carried out in a thermocycler (C 1000TM) with the following profile: initial denaturation at $94^{\circ} \mathrm{C}$ for $5 \mathrm{~min}$, followed by 35 cycles of three steps $\left(95^{\circ} \mathrm{C}\right.$ for $1 \mathrm{~min}, 55^{\circ} \mathrm{C}$ for $1 \mathrm{~min} 20 \mathrm{~s}$, and $72^{\circ} \mathrm{C}$ for $2 \mathrm{~min}$ ) and a final extension at $72^{\circ} \mathrm{C}$ for $5 \mathrm{~min}$. The PCR products were Sanger sequenced by Sangon Biotech (Shanghai) Co., Ltd.

All the raw sequences were assembled and edited using SeqMan (DNAstar package). The newly generated ITS sequences were complemented by sequences available in GenBank. Sequences were aligned using MAFFT version 7 with the L-INS-I alignment algorithm (Katoh et al. 2005), using the web server (http://mafft.cbrc.jp/alignment/server/) and with all parameters set to default values, and ambiguous regions were excluded using Gblocks (Talavera \& Castresana 2007) with the default settings. Phylogenetic relationships were inferred using Bayesian inference (BI) and under the maximum likelihood (ML) criterion.

BI analyses were performed using MrBayes v3.1.2 (Ronquist \& Huelsenbeck 2003). The optimal substitution model (GTR + $\mathrm{G})$ implemented in MrBayes was determined based on the Akaike information criterion (AIC) using jModelTest 3.7 (Posada 2008). BI analyses were run for 1000000 Markov chain Monte Carlo (MCMC) generations and with four incrementally heated chains; MCMC started from a random tree, and trees were sampled every 1000 generations, with the first $10 \%$ of the trees discarded as burn-in. Posterior probabilities (PPs) were obtained from the $95 \%$ majority-rule consensus tree of all saved trees.

ML analyses were performed with an online version of RAxML-HPC v8.2.12 (Stamatakis 2006), with the GTR + $\mathrm{G}$ model. All parameters in the ML analysis were set to the default, and statistical support values were estimated by 1000 nonparametric bootstrapping pseudoreplicates. ML bootstrap support (MLBS) values were obtained from the $70 \%$ majority-rule tree of all saved trees using RAxML. Trees were visualized in FigTree v1.4.0 (Rambaut 2012).

\section{RESULTS}

\section{PhylogeneTIC ANALYSES}

The alignment consisted of 48 ITS sequences (Table 1), 35 of which were newly generated in this study, and included H. kaernefeltii Divakar, A.Crespo, Sipman, Elix \& Lumbsch and H. dubitans (Sipman) Divakar, A.Crespo, Sipman, Elix \& Lumbsch as outgroup taxa. The results of ML and Bayesian analyses revealed 11 phylogenetically supported Everniastrum species. All species belonging to subgenus Everniastrum were clustered in one clade with high support (100\% MLBS and 1.00 PP), and four new species formed monotypic lineages with strong support (100\% MLBS, 1.00 PP and 98\% MLBS, $0.94 \mathrm{PP})$. Furthermore, these species were also supported by morphological, chemical and geographical characters, thus fully meriting recognition as new species, for which the names $H$. corallifera Xin Y.Wang \& Li S.Wang, sp. nov., $H$. longicilia Xin Y.Wang \& Li S. Wang, sp. nov., H. puerensis
Xin Y.Wang \& Li S.Wang, sp. nov., and H. yunnana Xin Y.Wang \& Li S. Wang, sp. nov., were coined (Fig. 1).

\section{TAXONOMY}

\section{Family PARMELIACEAE F.Berchtold \& J.Presl Genus Hypotrachyna (Vain.) Hale}

\section{Hypotrachyna alectorialica (W.L.Culb. \& C.F.Culb.)} Divakar, A.Crespo, Sipman, Elix \& Lumbsch

Phytotaxa 132 (1): 30 (2013).

Specimen EXAMINED. — India. West Bengal, Darjeeling; 2.XII.1920; Plitt (holo-, US[US]).

\section{Notes}

For a detailed description, see Culberson \& Culberson (1981). Morphologically, this species resembles $H$. nepalensis (Taylor) Divakar, A.Crespo, Sipman, Elix \& Lumbsch in having rhizines on the lower surface but differs in containing alectorialic acid. This species has been reported from India and South China (Yunnan Province, Culberson \& Culberson 1981), but none of our specimens from Yunnan contained alectorialic acid (several specimens from Yunnan listed under various species: $H$. catawbiensis, H. cirrhata (Fr.) Divakar, A.Crespo, Sipman, Elix \& Lumbsch, $H$. himlayana Divakar \& Kirika, $H$. corallifera Xin Y.Wang \& Li S.Wang, sp. nov., H. diffractaica (Y.M.Jiang \& J.C.Wei) Divakar, A.Crespo, Sipman, Elix \& Lumbsch, $H$. longicilia Xin Y.Wang \& Li S.Wang, sp. nov., H. mexicana (Egan) Divakar, A.Crespo, Sipman, Elix \& Lumbsch, H. nepalensis, H.puerensis Xin Y.Wang \& Li S.Wang, sp. nov., $H$. sinensis (J.B.Chen \& J.C.Wei) Divakar, A.Crespo, Sipman, Elix \& Lumbsch, H. subsorocheila (Y.M.Jiang \& J.C.Wei) Divakar, A.Crespo, Sipman, Elix \& Lumbsch, H. yunnana Xin Y.Wang \& Li S.Wang, sp. nov., H. vexans (Zahlbr. ex W.L.Culb. \& C.F.Culb.) Divakar, A.Crespo, Sipman, Elix \& Lumbsch). We believe that this species occurs in Yunnan. However, further investigation is needed to confirm the presence of $H$. alectorialica in China.

\section{Hypotrachyna catawbiensis (Degel.) Divakar,} A.Crespo, Sipman, Elix \& Lumbsch

Phytotaxa 132 (1): 31 (2013).

Selected SPeCimens eXamined. - China, Yunnan Prov.: Wuding Co., Shizi Mt; $102^{\circ} 22^{\prime} 43^{\prime \prime N}, 25^{\circ} 31^{\prime} 55^{\prime}$ "E; $2192 \mathrm{~m}$, on bark; 30.V.2011; E. D. Liu 11-2344; Wenshan Co., Baozhu Mt; 20²1.822'N, 103'54.624'E; 2870 m, on bark; 22.VI.2011; L. S. Wang 11-32165; Nanjian Co., Fenghuang Mt; 24 53'56.34”N, 100¹9'49.66”E; 2340 m, on Pinus bark; 14.VI.2012; L. S. Wang 12-34296; Kunming Ci., Aziying Vil.; $25^{\circ} 19.960^{\prime} \mathrm{N}, 102^{\circ} 50.956^{\prime} \mathrm{E} ; 2190$ m, on bark; 3.XI.2012; L. S. Wang 12-37158.

ECOLOGY AND DISTRIBUTION. - In China, this species usually grows on the bark of Pinus in the Hengduan Mts, at elevations of 2100$2800 \mathrm{~m}$. Elsewhere, it has been reported from North and South America, South Asia and East Africa and is widely distributed in the tropics (Culberson \& Culberson 1981; Sipman 1980). 


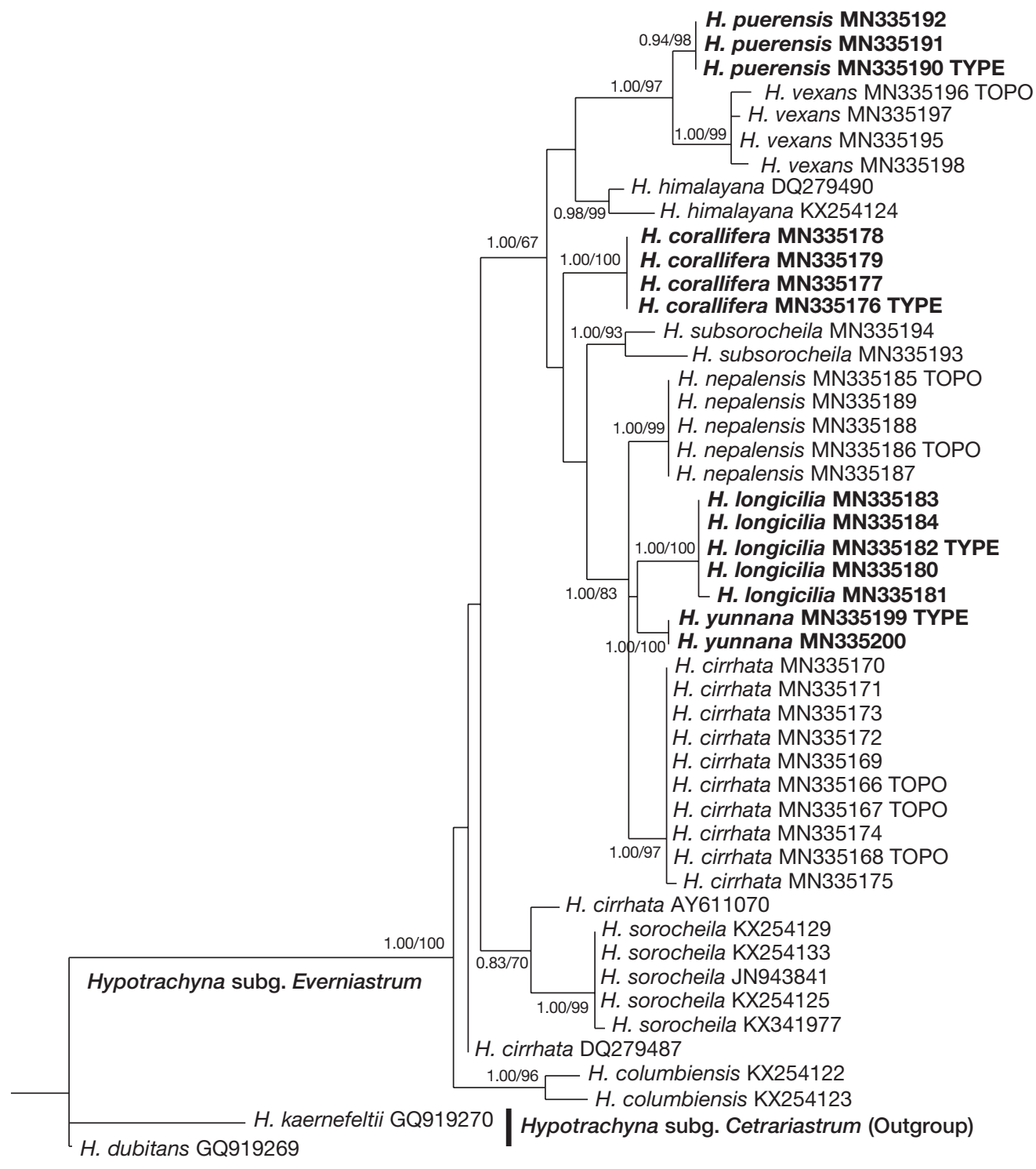

FIG. 1. - Phylogenetic tree generated from maximum likelihood (ML) analysis based on ITS sequence data. ML bootstrap support values greater than 70\% and Bayesian posterior probabilities (PPs) greater than 0.95 are given above the nodes. New species are indicated in bold. "TYPE" refers to the sequences of types, "TOPO" for specimens that come from the type locality. Scale bar: 0.02 substitutions.

\section{MORPHOLOGY}

\section{Thallus}

2-5 cm long, lobes 0.5-1 mm wide, lobe tips dichotomously branched, flat or involute, internodes 3-6 mm long.

\section{Upper surface}

Smooth, greyish green to pale ivory.

\section{Lower surface}

Smooth to slightly wrinkled, black in colour, turning brownish near the lobe tips.

\section{Cilia}

Sparse, 1-2 mm long, simple or sparingly branched.
Rhizines

Sparse or absent.

\section{Soredia}

Subterminal or laminal, erumpent and capitate.

Isidia

Absent.

Apothecia

Not seen.

Pycnidia

Not seen. 


\section{CHEMISTRY}

Cortex

$\mathrm{K}+$ yellow.

\section{Medulla}

$\mathrm{K}-$, C+ pinkish, P-. Containing gyrophoric acid.

\section{Notes}

The description is based on Chinese specimens.

This species resembles $H$. himalayana Divakar \& Kirika in having soredia; however, it contains gyrophoric acid instead of salazinic acid, and its soralia are usually subterminal to laminal, while in $H$. himalayana, the soralia are always terminal. New record to China.

\section{Hypotrachyna cirrhata (Fr.) Divakar, A.Crespo, Sipman, Elix \& Lumbsch}

Phytotaxa 132 (1): 31 (2013).

Selected materials examined. - China, Guizhou Prov.: Fanjing Mt, Jiulongchi; $1980 \mathrm{~m}$, on decaying bark; 25.V.1963; J. C. Wei 851 (HMAS); Kaili Ci., Leigongping; 26²1'5.115”N, 107³4'47.99"E; 1300 m, on bark; 20.V.1959; Qiannan Team 1839 (HMAS). Fujian Prov.: Wuyishan Ci., Huanggang Mt;

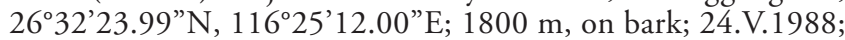
X. Q. Gao 2812 (HMAS). Yunnan Prov.: Shangrila Ci., Tianbao Mt; 27³6'24.40”N, 99 $53^{\prime} 03.54 ” E ; 3794$ m, on Salix bark; 6.VI.2012; L. S. Wang 12-35009.

Nepal, Bagmati Zone, Langtang National Park; 28¹3'5.93”N, $85^{\circ} 30$ '51.09"E; 3598 m, on bark; 6.XII.2017, H. X. Shi 17$57305,17-57318$.

\section{Notes}

For a detailed description, see Culberson \& Culberson (1981).

This species is characterized by having cilia on the lobe margin and a bare lower surface. The type specimen was collected from Nepal and published with a very brief description (Fries 1825). The brief description makes the taxonomic range of this species rather wide and unclear, and consequently, the species has been reported worldwide (Culberson \& Culberson 1981; Flakus et al. 2011; Jiang \& Wei 1993; Zahlbruckner 1930).

Specimens from the Hengduan Mountains (China) and from the type locality (Nepal), which have the characters of H. cirrhata s.l., formed a monophyletic clade with high support values (97\% MLBS and 1.00 PP). However, specimens from South and Central America were clustered in different clades (Fig. 1), indicating that they might belong to different species and that there might be cryptic species within $H$. cirrhata that have been overlooked due to a lack of clear morphological diagnostic characters.

Because the specimens from China and Nepal formed a well-supported clade, we assume that the specimens from this clade, with a bare lower surface and simple cilia along the lobe margin, belong to $H$. cirrhata sensu stricto and provide a reference for the delimitation of this species. More material collected globally and more sequences are needed to clarify the range of this species and the cryptic taxa mistakenly identified as this species.

\section{Hypotrachyna corallifera Xin Y.Wang \& Li S.Wang, sp. nov.}

(Fig. 2)

MYCOBANK NUMBER. - MB 832371.

ETYMOLOGY. - The epithet "corallifera" refers to the coralliform isidia.

TyPe. - China, Taiwan Prov., Jiayi Co., Alishan Forest Park; $23^{\circ} 30.602^{\prime} \mathrm{N}, 120^{\circ} 48.719^{\prime} \mathrm{E} ; 2283 \mathrm{~m}$, on Juniperus bark; 26.IX.2015; L. S. Wang 15-49365 (holo-, KUN[KUN]).

DiAGNOSIS. - This species is unique in having coralloid-branched isidia forming tufts, with lobules growing mixed with the isidia. The lobes are rather slim and involute. The species resembles $H$. vexans in having isidia, but it differs in its long and richly branched isidia mixed with lobules.

ECOlOgY AND DisTRIBUtion. - This species occurs in Yunnan and Taiwan, similarly to $H$. vexans, and usually grows on the bark of Quercus or Pinus, rarely on moss, at elevations of 1400-2300 m.

Selected specimens eXamined. - China, Yunnan Prov.: Shizong Co., Junzishan Mt; $24^{\circ} 41^{\prime} 19.43^{\prime \prime N}$, 10409'11.01”E; 2140 m, on Quercus bark; 5.XI.2014; L. S. Wang 14-47191; Nanjian Co., Jinguo Vil.; $24^{\circ} 48.701^{\prime} \mathrm{N}, 100^{\circ} 24.875^{\prime} \mathrm{E} ; 2230 \mathrm{~m}$, on moss; 25.V.2012; L. S. Wang 12-33723. Pu'er Ci., Xiaopingzhang Vil.; 22'42.374'N, $101^{\circ} 14.945^{\prime} \mathrm{E} ; 1420 \mathrm{~m}$, on bark; 18.I.2005; L. S. Wang 05-24173. Taiwan Prov., Jiayi Co., Alishan Forest Park; 2330.653’N, $120^{\circ} 48.984^{\prime} \mathrm{E}$; 2307 m, on Pinus bark; 26.IX.2015; L. S. Wang 15-49406.

\section{MORPHOLOGY}

Thallus

2-6 cm in diameter, lobes slim and involute, 0.5-1 mm wide, internodes 1-2 mm long, dichotomously branched, tips usually pointed and curving downward.

\section{Upper surface}

Smooth, greyish green to brownish grey (if stored in herbarium), densely isidiate.

\section{Isidia}

Numerous, $0.5-1.2 \mathrm{~mm}$ long, usually growing in the centre or at the tip of the lobe, forming tufts, coralloid-branched.

\section{Lobules}

Present among the isidia.

\section{Apothecia}

Not seen.

\section{Lower surface}

Smooth and bare, slightly wrinkled, dark brown in the centre, turning pale yellowish near the tips, rhizines absent.

\section{Cilia}

Sparse or absent, 0.8-2 mm long, simple or dichotomously branched. 
A
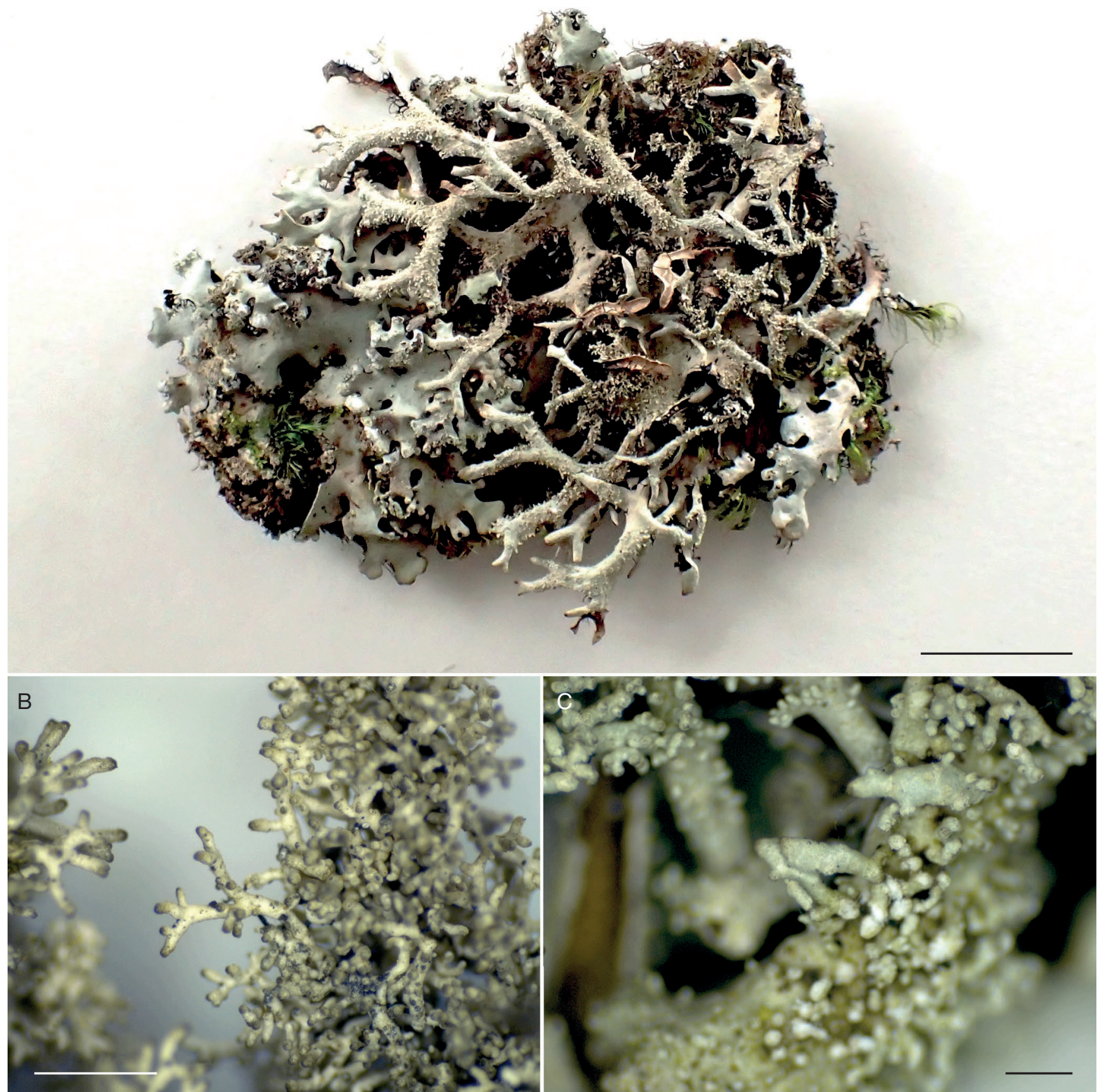

FiG. 2. - Hypotrachyna corallifera Xin Y.Wang \& Li S.Wang, sp. nov.: A, thallus; B, coralloid-branched isidia; C, lobules growing between isidia. Scale bars: $\mathrm{A}, 1 \mathrm{~cm} ; \mathrm{B}, \mathrm{C}, 1 \mathrm{~mm}$.

Soredia

Absent.

\section{Pycnidia}

Absent.

\section{CHEMISTRY}

Cortex

$\mathrm{K}+$ yellow.

\section{Medulla}

$\mathrm{K}+$ yellow to red, $\mathrm{C}-, \mathrm{P}+$ orange red, containing atranorin and salazinic acid (detected by TLC).

\section{NOTES}

This species is characterized by dense and coralloid-branched isidia on the upper surface and lobules growing between the isidia. Another isidiate species in China, $H$. vexans, differs from this new species by its small, laminal, granulose, 
marginal, and usually simple isidia without branches, often with lateral black cilia (Fig. 5D). Furthermore, $H$. vexans has flatter and wider lobes and lacks lobules. The phylogenetic tree based on specimens from the type locality (Taiwan Prov.) also supported this species as being different from $H$. vexans. $H$. fragilis has a type of isidia similar to that in this new species but differs by its absence of lobules, its long and fragile isidia (up to $3 \mathrm{~mm}$ ), mainly growing on the lobe tips and margins, and a different geographic distribution (South America).

\section{Hypotrachyna diffractaica (Y.M.Jiang \& J.C.Wei) Divakar, A.Crespo, Sipman, Elix \& Lumbsch}

Phytotaxa 132 (1): 31 (2013).

Selected Materials eXAmined. - China, Yunnan Prov.: Dali Ci., Cangshan Mt; $25^{\circ} 34^{\prime} \mathrm{N}, 100^{\circ} 13^{\prime} \mathrm{E}$; $3750 \mathrm{~m}$, on bark; 22.X.2002; J. C. Wei WY203 (HMAS-Neotype, selected in Chen et al. 2015); Cangshan Mt, TV station; 25 41'144”N, 1006'7”E; $2800 \mathrm{~m}$, on Pinus bark; 22.X.2002; L. S. Wang 02-22486; Nanjian Co., Dazhong Mt; $24^{\circ} 50^{\prime} 15.30^{\prime \prime} \mathrm{N}, 100^{\circ} 25^{\prime} 16.50$ ”'E; $2750 \mathrm{~m}$, on bark; 20.XII.2012; L. S. Wang 12-37774.

\section{NOTES}

For a detailed description, see Jiang \& Wei (1993).

This species is characterized by containing diffractaic acid, which is unique among the known Everniastrum species. The species has been reported from only Yunnan Province. Diffractaic acid was not found in our specimens ( 45 specimens - some of them are listed under H. nepalensis, H. sinensis and H. yunnana Xin Y.Wang \& Li S.Wang, sp. nov.) collected from the type locality (Dali Ci., Cangshan Mt), and we suppose that two chemotypes exist in Yunnan, a rare type with additional diffractaic acid and a more common type with atranorin and protolichesterinic and salazinic acids.

Apart from its chemical composition, this species can be distinguished by its large ascospores (up to $32 \mu \mathrm{m}$ long), apothecia growing on the terminal part of the lobes, with a distinct rugose podetium, and long marginal cilia (up to $2.5 \mathrm{~mm}$ long).

\section{Hypotrachyna himalayana Divakar \& Kirika}

\section{The Bryologist 119 (2): 178 (2016).}

SELECTED SPECIMENS EXAMINED. - Colombia, prope Bogota; $8500 \mathrm{ft}$ s.m.; J. Weir 5 pr. p. (H. sorocheila, holo-, BM[BM]).

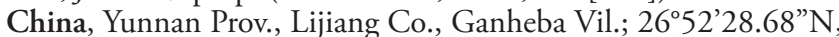
$100^{\circ} 14^{\prime} 9.545^{\prime \prime E ; ~} 3000$ m, on bark; 22.IX.1987; J. C. Wei 9282 (HMAS). Xundian Co., Hekou Vil., Xuzhao Temple; 2538'23.97”N $103^{\circ} 22^{\prime} 58.91^{\prime} \mathrm{E} ; 1900 \mathrm{~m}$, on bark; 16.VI.2015; X. Y. Wang 1547332. Guizhou Prov., Shiqian Co., Shigu Forest reserve; $900 \mathrm{~m}$, on decaying bark; 11.VII.1988; L. S. Wang 88-21186. Xizang Prov., Nyalam Co., Quxiang Vil.; 286'5.115”N, 85³4'11.99”E; 3550 m, on bark; 19.V.1966; J. C. Wei 926, 929-1 (HMAS).

\section{NoTES}

For a detailed description, see Kirika et al. (2016).
This species can be distinguished by the lip-shaped soralia growing on the lower surface of the lobe tips and by containing atranorin and salazinic acid as the main compounds. It is distinguished from other sorediate species in China as follows. It differs from $H$. catawbiensis by its anchor-shaped soralia on the lobe tips, while in $H$. catawbiensis, the soralia are usually laminal. Furthermore, it contains gyrophoric acid (medulla K-, C+ red) instead of salazinic acid (medulla $\mathrm{K}+$ yellow turning red, C-). $H$. subsorocheila has wider and shorter lobes, the upper surface is pustulate and forms soralia, and salazinic and gyrophoric acids are absent (medulla K-, C-); it has characters identical to those in $H$. sorocheila but is distinct in its position on the phylogenetic tree and its geographic distribution, as it is restricted to Asia, whereas H. sorocheila is mainly distributed in South America and currently not known from Asia (Kirika et al. 2016). Moreover, these two species formed two distinct clades in the tree (Fig. 1), consistent with the result of Kirika. Thus, the previous report of $H$. sorocheila in China (Chen et al. 2015) should be revised as H. himalayana.

\section{Hypotrachyna longicilia Xin Y.Wang \& Li S. Wang, sp. nov.} (Fig. 3)

MYCOBANK NUMBER. - MB 832372.

Etymology. - The epithet "longicilia" refers to the long and curved cilia.

Diagnosis. - This species is characterized by dense, long and curved marginal cilia up to $3.5 \mathrm{~mm}$ long, which are dichotomously to irregularly branched. It resembles $E$. diffractaicum in its long cilia but differs in lacking diffractaic acid, its longer cilia, its smaller ascospores and its subtropical distribution.

TYPe. - China, Yunnan Prov., Yuanyang Co., Xiguanyin Mt; $23^{\circ} 10^{\prime} 60^{\prime \prime} \mathrm{N}, 102^{\circ} 37^{\prime} 41^{\prime \prime} \mathrm{E} ; 2600 \mathrm{~m}$, on bark; 27.XI.2011; D. Liu 11-467a (holo-, KUN[KUN]).

China, Taiwan Prov., Jiayi Co., Alishan National Park; 2307 m, on Pinus bark; 26.IX.2015; L. S. Wang 15-49399.

ECOlOGY AND DisTRIBUTION. - This species is common in the southern part of the Hengduan Mts and of Taiwan Province, with a subtropical distribution. It usually grows on the bark of Pinus or Salix, at elevations of 1900-2800 m.

Selected specimens examined. - China, Yunnan Prov., Gongshan Co., Dongshaofang Vil.; $27^{\circ} 42.164^{\prime} \mathrm{N}$, 98 $29.671^{\prime} \mathrm{E}$; $2500 \mathrm{~m}$, on Coriaria bark; 2.VI.2000; L. S. Wang 00-19064; Jingdong Co., Ailao Mt, Xujiaba Reservoir; $24^{\circ} 32^{\prime} 808^{\prime \prime} \mathrm{N}, 1^{\circ} 01^{\circ} 01^{\prime} 367^{\prime \prime} \mathrm{E} ; 2460 \mathrm{~m}$, on bark; 21.I.2005; L. S. Wang 05-23664. Xizang Prov., Motuo Co., Gawalong Snow Mt; $29^{\circ} 42.674^{\prime} \mathrm{N}, 95^{\circ} 35.402^{\prime} \mathrm{E} ; 2830 \mathrm{~m}$, on Sorbus bark; 19.IX.2014; L. S. Wang 14-46034. Taiwan Prov., Jiayi Co., Alishan National Park; 2273 m, on Magnolia bark; 26.IX.2015; L. S. Wang 15-49417, 15-49424.

\section{MORPHOLOGY}

Thallus

$3-10 \mathrm{~cm}$ in diameter, lobes $0.8-1.2 \mathrm{~mm}$ wide, flat or slightly involute, rather slim and long, internodes 5-8(-15) mm long, dichotomously branched, tips usually pointed.

Upper surface

Smooth, greyish green to pale grey. 
A
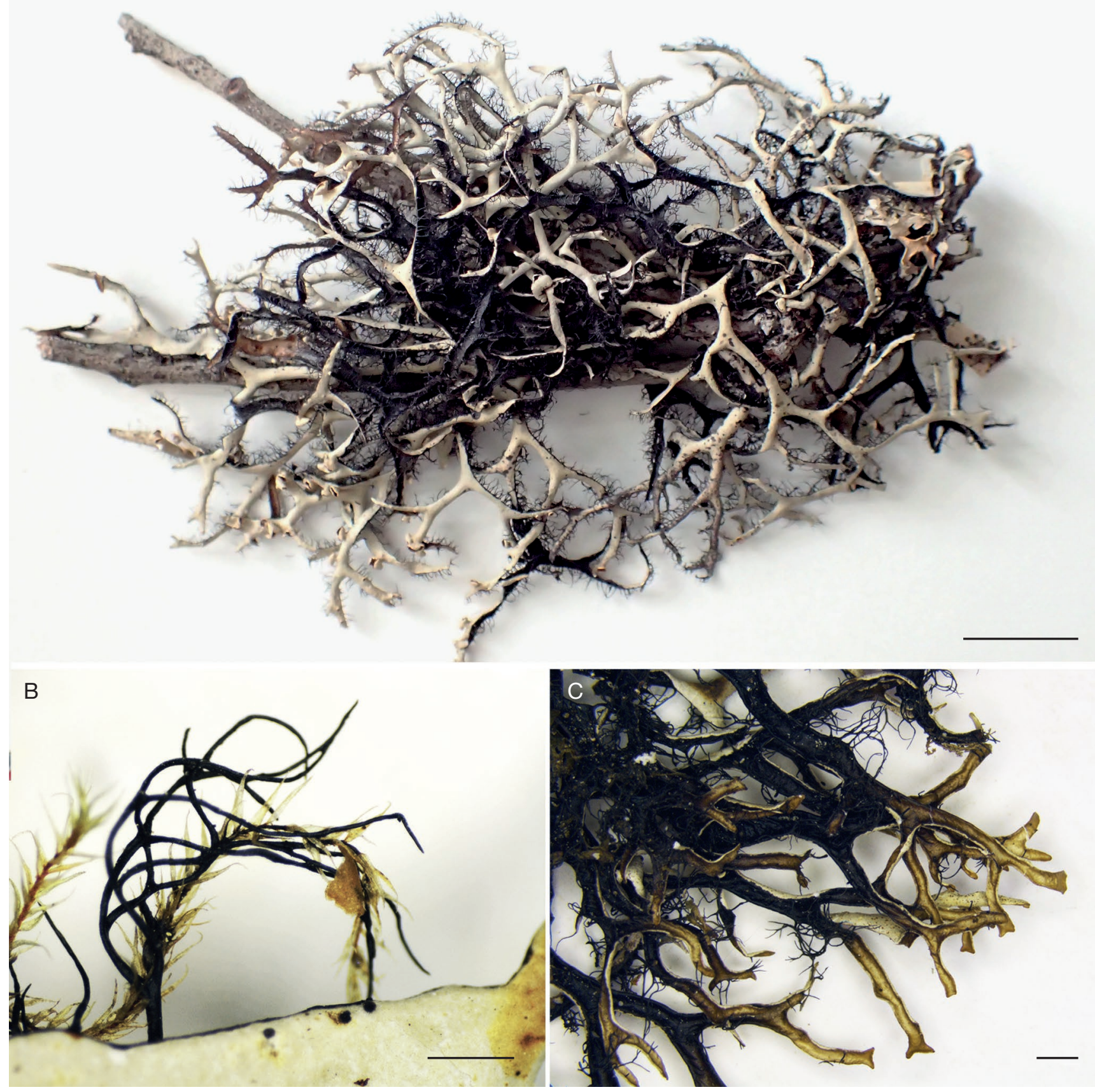

FIG. 3. - Hypotrachyna longicilia Xin Y.Wang \& Li S.Wang, sp. nov.: A, thallus; B, long, curved and branched cilia; C, bare lower surface. Scale bars: A, $1 \mathrm{~cm}$ $\mathrm{B}, 1 \mathrm{~mm} ; \mathrm{C}, 2 \mathrm{~mm}$.

Lower surface

Strongly wrinkled, black in the centre, turning dark brown near the lobe tips.

\section{Cilia}

Rather dense, 1.5-3(-3.5) mm long, curved, dichotomously to irregularly branched.

\section{Rhizines}

Absent.
Soredia and isidia

Absent.

\section{Lobules}

Absent.

\section{Apothecia}

Subterminal, disc yellowish brown to reddish brown, $1-3(-5) \mathrm{mm}$ in diameter, podetium usually smooth, ascus 8-spored, spores kidney-shaped, 20-22 × 5-7 $\mu \mathrm{m}$. 
Pycnidia

Not seen.

\section{CHEMISTRY}

Cortex

$\mathrm{K}+$ yellow.

\section{Medulla}

$\mathrm{K}+$ yellow turning red, $\mathrm{C}-, \mathrm{P}+$ orange. Containing atranorin and salazinic acid (detected by TLC).

\section{NOTES}

This species can be distinguished from all the other Chinese species by its long, curved and branched cilia; the cilia usually attach to the substrate or to nearby lobes. Furthermore, the lobes are rather long and slim, forming long internodes (up to $15 \mathrm{~mm}$ long). H. diffractaica, having long cilia, might be confused with this species, but $H$. longicilia Xin Y.Wang \& Li S.Wang, sp. nov., has much longer (up to $3.5 \mathrm{~mm}$ ) and denser cilia, shorter ascospores, and a subtropical distribution. Specimens of $H$. cirrhata with long cilia resemble this species, but the lobes of $H$. longicilia Xin Y.Wang \& Li S.Wang, sp. nov., are much slimmer and longer (internodes up to $15 \mathrm{~mm}$ long), and the cilia are dense, usually curved and with branches, whereas in $H$. cirrhata, the cilia are usually sparse, short, simple and without branches.

\section{Hypotrachyna mexicana (Egan) Divakar, A.Crespo, Sipman, Elix \& Lumbsch}

Phytotaxa 132 (1): 31 (2013).

Selected Specimens EXAmined. - Mexico, Jalisco: Combre de Tejamanil, Mpio. de Jalapa; 2200 m, on trees; 25.X.1971; González, 1971 (holo-, US[US]).

China, Yunnan Prov., Fengshan Co., Fengshan Mt; 1650 m, on Camelia bark; 11.X.1959; Q. Z. Wang 2a (HMAS); Tengchong Co., Gaoligongshan Mt; 2517'56”N, 9842'12”E; $2048 \mathrm{~m}$, on bark; 11.VII.2014; W. Z. Ma 14-L5738; Nanjian Co., Fenghuangshan Mt; $24^{\circ} 53^{\prime} 56.34$ ”N, $100^{\circ} 19^{\prime} 49.66^{\prime \prime E}$; 2340 m, on Pinus bark; 14.VI.2012; L. S. Wang 12-34294.

\section{NoTES}

For a detailed description, see Egan (1978).

This species is characterized by the absence of salazinic acid and by a white to pale brown lower surface with sparse rhizines. The marginal cilia are sparse and short but sometimes numerous and long, up to $2 \mathrm{~mm}$ long (Culberson \& Culberson 1981). This species resembles $H$. cirrhata in morphology but differs in the absence of salazinic acid, the presence of protocetraric acid (medulla $\mathrm{K}-, \mathrm{KC}+$ pale red), and a white lower surface near the tips.

\section{Hypotrachyna nepalensis (Taylor) Divakar, A.Crespo, Sipman, Elix \& Lumbsch}

Phytotaxa 132 (1): 32 (2013).
Selected specimens examined. - China, Yunnan Prov., Wenshan Co., Bozhu Vil., Bozhu Mt; 20²1.822’N, 10354.624'E; 2870 m, on bark; 22.VII.2011; L. S. Wang 11-32167. Dali Co., Cangshan Mt; $25^{\circ} 41.111^{\prime} \mathrm{N}, 100^{\circ} 06.244^{\prime} \mathrm{E} ; 3160 \mathrm{~m}$, on bark; 14.VIII.2011; L. S. Wang 11-32278. Lijiang Co., Yulong Snow Mt; 2900 m, on bark; 13.VIII.1982; L. S. Wang 82-866. Sichuan Prov., Liangshan

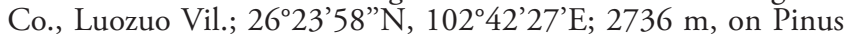
bark; 24.VII.2011; L. S. Wang 11-2237.

Nepal, Bagmati Zone, Langtang National Park; 2809'39.91"N, $85^{\circ} 25^{\prime} 46.07^{\prime \prime} \mathrm{E} ; 2471 \mathrm{~m}$, on bark; 4.XII.2017; H. X. Shi 1757200, 17-57221.

\section{NOTES}

For a detailed description, see Culberson \& Culberson (1981).

This species is characterized by the presence of dense rhizines on the lower surface, marginal cilia usually simple and less than $1 \mathrm{~mm}$ long, slim lobes, and the presence of protocetraric and salazinic acids. H. subnepalensis (holo-, US[US]!) is morphologically identical but differs in containing fumarprotocetraric acid.

H. nepalensis is widely distributed in Asia, growing in the mountains of Yunnan, Nepal, India, Thailand and Java (Culberson \& Culberson 1981), and usually grows on shrubs and trees. Local people from northwestern Yunnan use this species as a medicine (raw material for antibiotics). We used specimens from the type locality in Nepal and the nearby region of China for an estimation of the phylogenetic position of the species (Fig. 1). This phylogenetic analysis confirmed the monophyly of the species, providing a reference for its delimitation.

\section{Hypotrachyna puerensis Xin Y.Wang \& Li S.Wang, sp. nov.} (Fig. 4)

\section{MycoBAnK nUmBer. — MB 832373.}

Etymology. - The epithet "puerensis" refers to the type locality, Pu'er city in southern Yunnan Province.

DiagNOSIs. - This species is unique in its light brown to yellowish white colour, bare lower surface, absence of marginal cilia, and protocetraric acid and atranorin contents (medulla K-). It resembles $H$. lipidifera in the absence of salazinic acid and the bare lower surface, but the latter species has sparse marginal cilia and does not produce protocetraric acid.

TyPe. - China, Yunnan Prov., Pu'er Ci., roadside forest along the old road from Pu'er to Kunming; 22 52 '08.47”N, 10059'25.61"E; 1548 m, on bark; 20.XII.2013; X. Y. Wang 13-41509 (holo-, KUN[KUN]).

ECOLOGY AND DISTRIBUTION. - This species is found in the southern Yunnan subtropical forest. It usually grows in the broadleaf forest at elevations of $1500-2300 \mathrm{~m}$.

Selected specimens examined. - China, Yunnan Prov., Pu'er $\mathrm{Ci}$., roadside forest along the old road from Pu'er to Kunming; $22^{\circ} 52^{\prime} 08.47$ ”N $100^{\circ} 59^{\prime} 25.61 " \mathrm{E} ; 1548 \mathrm{~m}$, on bark; 20.XII.2013; X. Y. Wang 13-41500. Nanjian Co., Baohua Vil., Dazhong Mt; $24^{\circ} 51^{\prime} 04.62 " \mathrm{~N}, 100^{\circ} 26^{\prime} 21.80^{\prime \prime} \mathrm{E} ; 2040 \mathrm{~m}$, on bark; 20.XII.2012; L. S. Wang 12-37680. Zhenyuan Co., Hepingxiang Vil.; 2356'22.43”'N, $101^{\circ} 29^{\prime} 05.14$ ”'E; 2300 m, on bark; 1.VII.2013; C. Z. Fan 13-38611. 
A
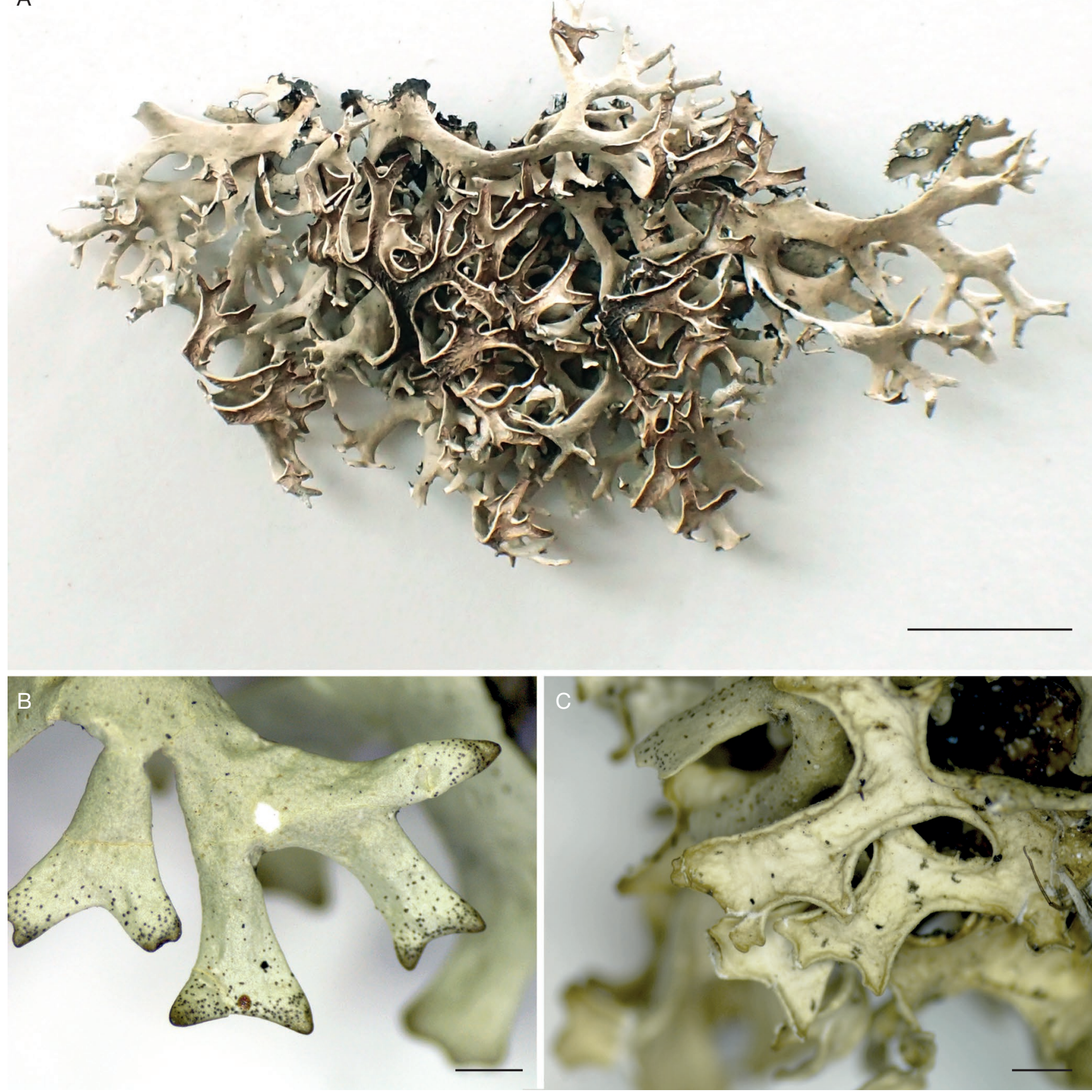

FIG. 4. - Hypotrachyna puerensis Xin Y.Wang \& Li S.Wang, sp. nov.: A, thallus without cilia; B, lobes with pointed tips; C, pale yellowish brown, bare lower surface. Scale bars: A, $1 \mathrm{~cm}$; B, C $1 \mathrm{~mm}$.

\section{MORPHOLOGY}

\section{Thallus}

2-6 $\mathrm{cm}$ in diameter, lobes 0.6-1 mm wide, slim and short, internodes 3-6 mm long, dichotomously branched, tips usually pointed.

\section{Upper surface}

Smooth, greyish green to pale grey, tip part usually black.

\section{Lower surface}

Smooth, sometimes wrinkled, brown in the centre, turning light brown to yellowish white near the lobe tips.
Cilia

Absent or very rare along the mature lobes.

\section{Rhizines}

Absent in the tips, growing sparsely near the lobe centre.

Soredia and isidia

Absent.

Lobules

Absent. 
Apothecia

Not seen.

Pycnidia

Not seen.

CHEMISTRY

Cortex

$\mathrm{K}+$ yellow.

Medulla

$\mathrm{K}-, \mathrm{C}-, \mathrm{P}+\mathrm{red}$, containing atranorin and protocetraric acid (detected by TLC).

\section{NoTE}

This species can be separated from all the other Chinese species by the bare lower surface tip and bare margin, the absence of salazinic acid (medulla K-), and the presence of protocetraric acid. It resembles $H$. mexicana in the whitish lower surface and the presence of protocetraric acid, but the latter species has sparse to dense marginal cilia, wider lobes (up to $2.5 \mathrm{~mm}$ wide) and no rhizines on the lower surface. This species might be confused with specimens of $H$. cirrhata with sparse cilia, but the latter species always contains salazinic acid (medulla $\mathrm{K}+\mathrm{red}$ ) and grows at higher elevations, whereas $H$. puerensis Xin Y.Wang \& Li S.Wang, sp. nov., has a more subtropical distribution.

In the phylogenetic tree (Fig. 1), H. puerensis Xin Y.Wang \& Li S.Wang, sp. nov., formed a monophyletic clade, sister to the $H$. vexans clade but not close to $H$. cirrhata.

\section{Hypotrachyna rhizodendroidea (J.C.Wei \& Y.M.Jiang) Divakar, A.Crespo, Sipman, Elix \& Lumbsch}

Phytotaxa 132 (1): 32 (2013).

Selected specimens eXamined. - China, Xizang Prov., Nyalam Co., Quxiang Vil.; 286'5.115”N, 85³4'11.99”E; 3740 m, on shrubs; 1.V.1966; J. C. Wei 762 (holo-, HMAS[HMAS]); Nyalam Co., Boquhe River; $28^{\circ} 6^{\prime} 5.115^{\prime \prime N}, 85^{\circ} 34^{\prime} 11.99^{\prime \prime} \mathrm{E} ; 3650$ m, on Rhododendron bark; 14.VI.1996; J. C. Wei 1555-1 (HMAS).

\section{NOTES}

For a detailed description, see Wei \& Jiang (1982).

This species can be separated from all other known species of Everniastrum by its special cilia type - short, thick, fruticose, irregularly and richly branched (Fig. 5A), the lower surface covered with sparse rhizines, and atranorin and salazinic acid as the main compounds. It was first reported from Xizang Province and usually grows on shrubs at elevations of 2300$3800 \mathrm{~m}$. However, no specimens examined in this study, including those collected from the type locality, had exactly the same morphological characters as the type specimen. The phylogenetic analysis also supported this view (Fig. 1): our specimens (GenBank Nos: MN335186, MN335188) with branched cilia were clustered within the $H$. nepalensis clade, indicating that these specimens with branched cilia were not
H. rhizodendroidea. The concept of this species needs further study with fresh material having the proper type of cilia from the type locality.

\section{Hypotrachyna sinensis (J.B.Chen \& J.C.Wei) Divakar, A.Crespo, Sipman, Elix \& Lumbsch}

Phytotaxa 132 (1): 32 (2013).

Selected SPeCimens eXamined. - China, Hubei Prov., Shennongjia Forest Reserve; $31^{\circ} 26^{\prime} 59.99^{\prime \prime N}, 110^{\circ} 24^{\prime 2} 2.046$ "E; 2200 m, on Pinus bark; 15.VII.1984; J. B. Chen 10488 (holo-, HMAS[HMAS]). Yunnan Prov., Dali Co., Cangshan Mt; $25^{\circ} 41^{\prime} \mathrm{N}, 100^{\circ} 06^{\prime} \mathrm{E} ; 3400 \mathrm{~m}$, on Pinus bark; 12.VI.2005; L. S. Wang 05-24650. Binchuan Co., Jizushan Mt; $25^{\circ} 57.847^{\prime} \mathrm{N}, 100^{\circ} 22.151^{\prime} \mathrm{E} ; 2620 \mathrm{~m}$, on bark; 13.III.2012; L. S. Wang 12-33460. Deqin Co., Yubeng Vil.; $28^{\circ} 23.922^{\prime} \mathrm{N}$, $98^{\circ} 46.155^{\circ} \mathrm{E}$; $3500 \mathrm{~m}$, on bark; 14.XII.2012; D. L. Niu 12-36347.

\section{NoTes}

For a detailed description, see Chen et al. (1989).

This species is unique in having lobules on the upper surface (Fig. 5B). This character separates $H$. sinensis from all the other species in the subgenus Everniastrum. Furthermore, its upper surface is rather rugose, and the species contains atranorin and salazinic acid as the main compounds. It was first reported from Hubei Province, Shennongjia, and new collections from Yunnan Province were found during this study. It usually grows on bark, rarely on rock, at elevations of 2200-3400 m, and it is currently known only from China.

\section{Hypotrachyna subsorocheila (Y.M.Jiang \& J.C.Wei)} Divakar, A.Crespo, Sipman, Elix \& Lumbsch

Phytotaxa 132 (1): 33 (2013).

Selected specimens examined. - China, Yunnan Prov., Lijiang Co., Yuhucun Vil.; 26 $52^{\prime} \mathrm{N}, 100^{\circ} 14^{\prime} \mathrm{E} ; 2700 \mathrm{~m}$, on Pinus bark; 25.IV.1987; J. C. Wei 9247 (holo-, HMAS[HMAS]). Lijiang Co., Ganheba Vil.; 26²'28.68”N, 100¹4'9.545”E; 3000 m, on Pinus bark; 22.IV.1987; J. C. Wei 9280, 9284 (HMAS). Lijiang Co., Yuhucun Vil.; 2900 m, on Pinus bark; 14.VIII.1982; L. S. Wang 82-1234, 82-930. Taiwan Prov., Jiayi Co., Alishan Forest Park; $23^{\circ} 30.602^{\prime} \mathrm{N}$, $120^{\circ} 48.719^{\prime} \mathrm{E} ; 2307 \mathrm{~m}$, on bark; 26.IX.2015; L. S. Wang 15-49364, 15-49429.

\section{NoTes}

For a detailed description, see Jiang \& Wei (1989).

H. subsorocheila can be distinguished by its pustular upper surface, forming granulose soralia, which are concolorous with the thallus or turning blackish and spread from the tip to the centre of the lobes; the lobes are usually wide and short (Fig. 5C). Salazinic acid is absent. Two other sorediate species, $H$. himalayana and $H$. sorocheila, also have soralia, but the soralia are powdery and white in these species and grow only on the lower surface of the lobe tips; the lobes are slim and anchor-shaped, and they contain salazinic acid. Furthermore, our phylogenetic analysis (Fig. 1) revealed that $H$. subsorocheila (GenBank Nos: MN335193, MN335194) was not clustered with $H$. sorocheila or $H$. himalayana. 


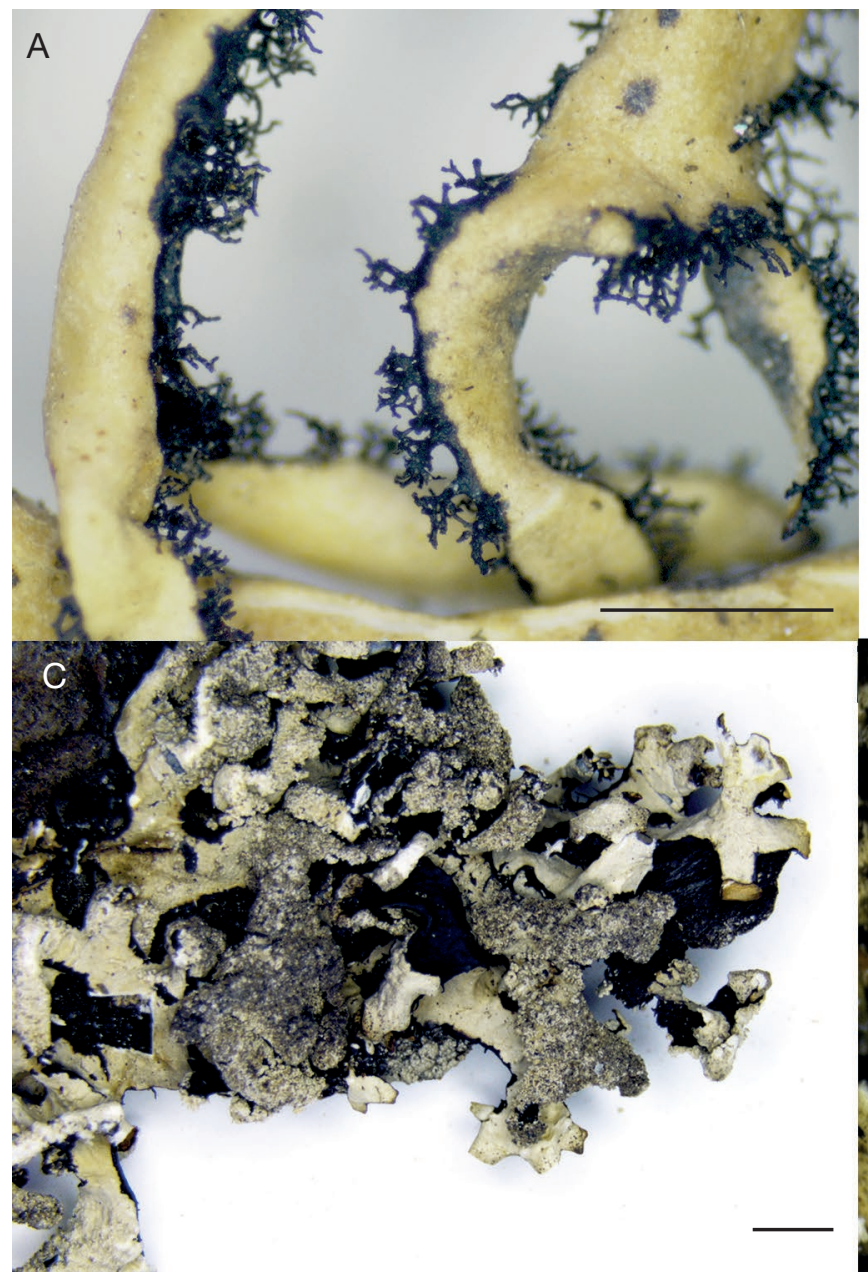

B
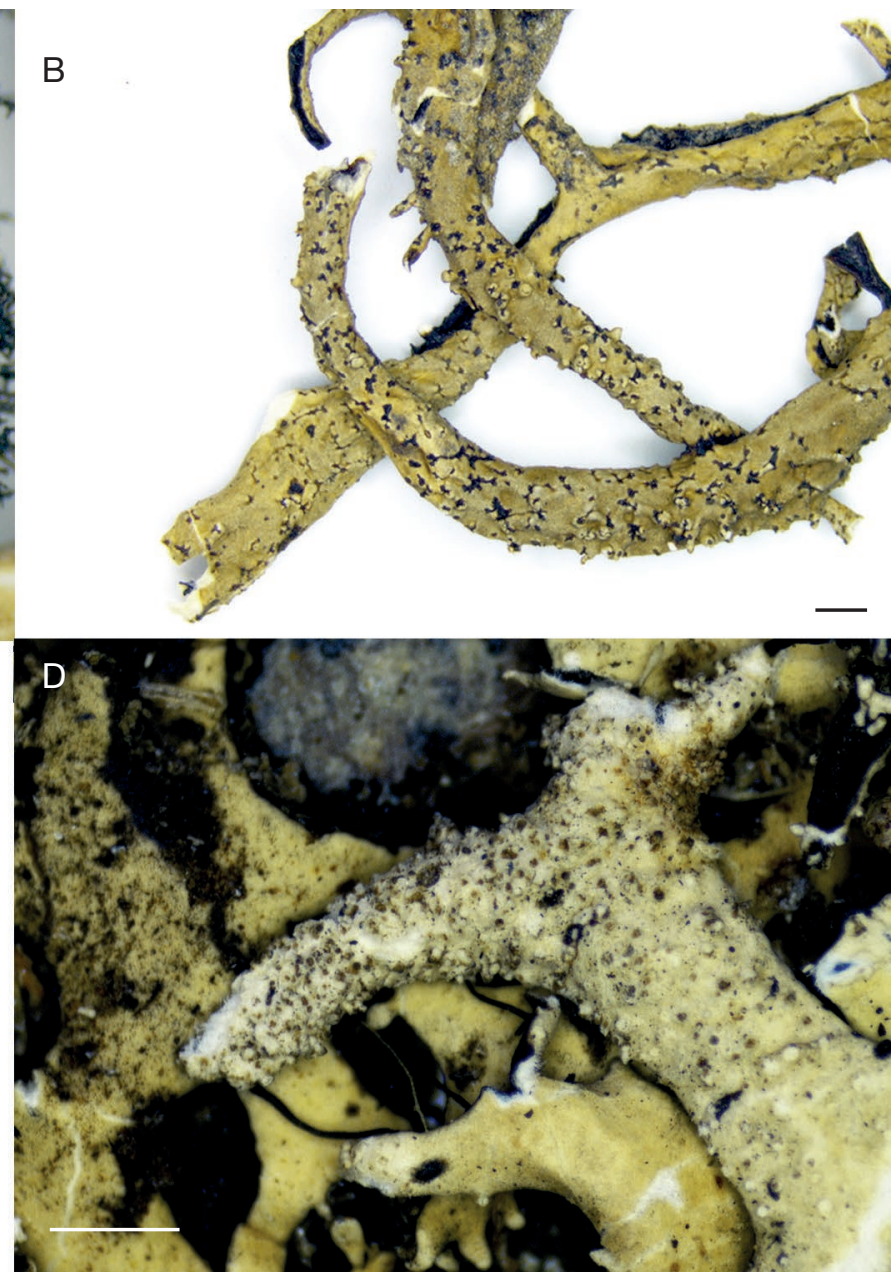

FIG. 5. - Type specimens showing special characters: A, Hypotrachyna rhizodendroidea (J.C.Wei \& Y.M.Jiang) Divakar, A.Crespo, Sipman, Elix \& Lumbsch showing short, thick and irregularly branched cilia (J. C. Wei 762, HMAS); B, H. sinensis (J.B.Chen \& J.C.Wei) Divakar, A.Crespo, Sipman, Elix \& Lumbsch showing lobules on the upper surface (J. B. Chen 10488, HMAS); C, H. subsorocheila (Y.M.Jiang \& J.C.Wei) Divakar, A.Crespo, Sipman, Elix \& Lumbsch showing granulose soralia (J. C. Wei 9247, HMAS); D, H. vexans (Zahlbr. ex W.L.Culb. \& C.F.Culb.) Divakar, A.Crespo, Sipman, Elix \& Lumbsch showing short and granulose isidia on the upper surface (Asahina 79, W). Scale bar: A, B, D, $1 \mathrm{~mm}$; C, $2 \mathrm{~mm}$.

\section{Hypotrachyna yunnana Xin Y.Wang \& Li S.Wang, sp. nov.}

(Fig. 6)

MycoBAnK NUMBER. - MB 832374.

ETyMology. - The epithet "yunnana" refers to the type locality, Yunnan Province.

DiAgnOSIS. - This species is unique in its thick and wide lobes, which are up to $5 \mathrm{~mm}$ wide. The lobe upper surface is covered with bundles of cilia, the margin of lobes usually shows a thick black rim covered with dense, short, shrubby, and dichotomously branched cilia, and the lower surface is covered with simple or branched rhizines.

TyPe. - China, Yunnan Prov., Nanjian Co., Wuliang Medicine Valley; 2452'2.76” N, 100³4'51.39”E; 2348 m, on Vaccinium bark; 19.XII.2012; L. S. Wang 12-37635 (holo-, KUN[KUN]).

ECOlogy And Distribution. - This species is found in Yunnan only, mainly in the northwest, growing on bark of Abies, Pinus, Vaccinium or sometimes on soil over rock, at elevations of 2200-3100 m.

Selected specimens eXamined. - China, Yunnan Prov., Nanjian Co., Wuliangshan Mt; 244․ $213^{\prime} \mathrm{N}, 100^{\circ} 30.131^{\prime} \mathrm{E} ; 2340$ m, on bark; 22.III.2012; L. S. Wang 12-33039. Nanjian Co., Fenghuang Mt; $24^{\circ} 53^{\prime} 43.60^{\prime \prime} \mathrm{N}, 100^{\circ} 19^{\prime} 52.22^{\prime \prime E} ; 2360$ m, on Vaccinium bark; 14.VI.2012; L. S. Wang 12-34276. Dali Co., Cangshan Mt; $25^{\circ} 41.111^{\prime} \mathrm{N}, 100^{\circ} 06.244{ }^{\prime} \mathrm{E} ; 3410 \mathrm{~m}$, on soil over rock; 14 .VIII.2011; L. S. Wang 11-32263. Gongshan Co., Yeniu Valley; $27^{\circ} 48.045^{\prime} \mathrm{N}$, $98^{\circ} 49.518^{\prime} \mathrm{E} ; 2950 \mathrm{~m}$, on Abies bark; 30.V.2000; L. S. Wang 00-19359.

\section{MORPHOLOGY}

Thallus

$6-15 \mathrm{~cm}$ in diameter, lobes rather thick and wide, $2-5 \mathrm{~mm}$ wide, internodes 5-10 mm long, dichotomously branched, tips usually pointed.

\section{Upper surface}

Rugose, greyish green to brownish grey (if stored in herbarium), marginal part with thick, black rim, bundled cilia sparsely growing on the upper surface, marginal cilia dense and shrubby, 0.3-0.5 mm long, dichotomously branched.

\section{Lower surface}

Smooth and shiny, slightly wrinkled, black in the centre, turning dark brown near the tips. 
Rhizines

Dense in the centre, turning moderate near the tips, simple or dichotomously branched, short and black, 0.3-0.6 mm long.

Soredia and isidia

Absent.
Lobules

Absent.

\section{Apothecia}

Rare, subterminal, disc chestnut brown, 2-8 $\mathrm{mm}$ in diameter, ascus 8-spored, spores kidney-shaped, 5-7 × 20-23 $\mu \mathrm{m}$.

\section{Key to Hypotrachyna subgenus Everniastrum (Hale ex Sipman) Divakar, A.Crespo, Sipman, Elix \& Lumbsch SPECIES FROM CHINA}

1. Lower surface, especially near the tips bare, without rhizines

— Lower surface covered with rhizines

2. Marginal cilia absent, lower surface yellowish white

H. puerensis Xin Y.Wang \& Li S.Wang, sp. nov.

- Marginal cilia present, sparse or dense 3

3. Soredia or isidia present

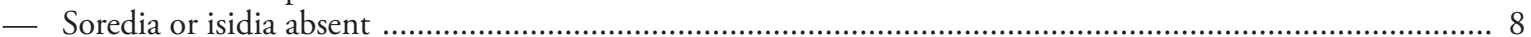

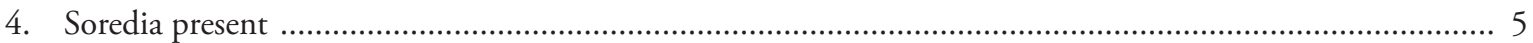

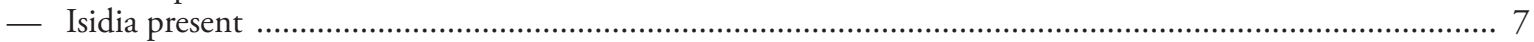

5. Soralia at the tip on the lower surface, whitish and lip-shaped, medulla $\mathrm{K}+\mathrm{red}$, with salazinic acid

........................................................................................................ H. himalayana Divakar \& Kirika

- Soralia pustulate, terminal to laminal on the upper surface, medulla K-, lacking salazinic acid .................. 6

6. Medulla $\mathrm{C}+$ pink, with gyrophoric acid

- Medulla C-, without gyrophoric acid H. catawbiensis (Degel.) Divakar, A.Crespo, Sipman, Elix \& Lumbsch H. subsorocheila (Y.M.Jiang \& J.C.Wei) Divakar, A.Crespo, Sipman, Elix \& Lumbsch

7. Isidia simple, granular to cylindrical, lobules absent H. vexans (Zahlbr. ex W.L.Culb. \& C.F.Culb.) Divakar, A.Crespo, Sipman, Elix \& Lumbsch

- Isidia long and coralloid-branched, forming tufts, mixed with lobules H. corallifera Xin Y.Wang \& Li S.Wang, sp. nov.

8. Upper surface covered with lobules

- Upper surface bare H. sinensis (J.B.Chen \& J.C.Wei) Divakar, A.Crespo, Sipman, Elix \& Lumbsch

9. Cilia long and curved, irregularly branched, up to $3.5 \mathrm{~mm}$ long

- Cilia simple without branches, less than $2 \mathrm{~mm}$ long H. longicilia Xin Y.Wang \& Li S.Wang, sp. nov. H. cirrhata (Fr.) Divakar, A.Crespo, Sipman, Elix \& Lumbsch

10. Upper surface rough, covered with tufts of cilia H. yunnana Xin Y.Wang \& Li S.Wang, sp. nov.

- Upper surface smooth, without cilia

11. Cilia branched

- Cilia simple or absent

12. Cilia long and branched, with diffractaic acid

H. diffractaica (Y.M.Jiang \& J.C.Wei) Divakar, A.Crespo, Sipman, Elix \& Lumbsch

- Cilia short and shrubby-branched, without diffractaic acid H. rhizodendroidea (J.C.Wei \& Y.M.Jiang) Divakar, A.Crespo, Sipman, Elix \& Lumbsch

13. Medulla K-, without salazinic acid

- Medulla K+ red, with salazinic acid H. mexicana (Egan) Divakar, A.Crespo, Sipman, Elix \& Lumbsch

14. Alectorialic acid present

- Alectorialic acid absent H. alectorialica (W.L.Culb. \& C.F.Culb.) Divakar, A.Crespo, Sipman, Elix \& Lumbsch H. nepalensis (Taylor) Divakar, A.Crespo, Sipman, Elix \& Lumbsch 
A
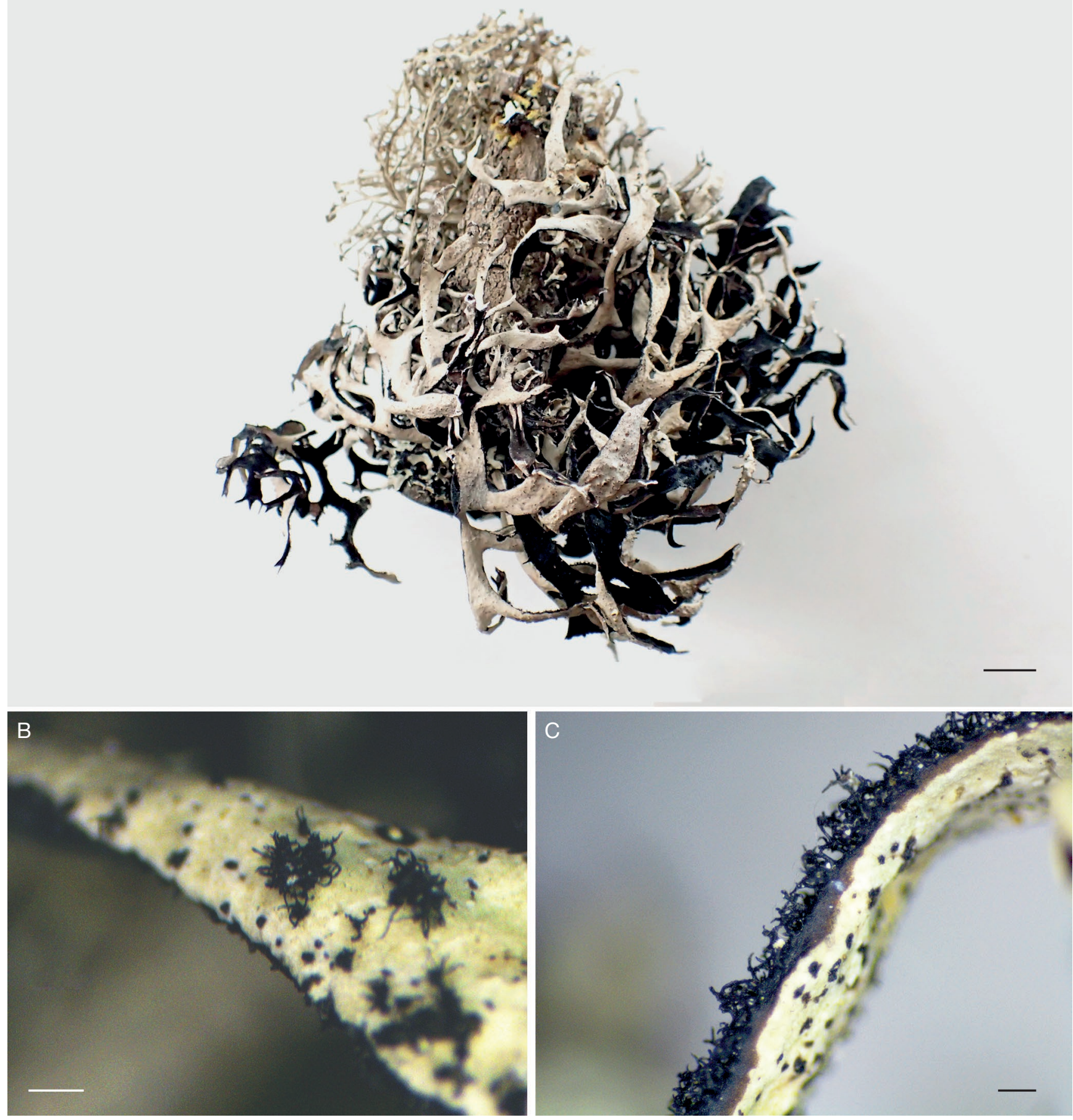

FIG. 6. - Hypotrachyna yunnana Xin Y.Wang \& Li S.Wang, sp. nov.: A, thallus with wide lobes; B, bundled cilia on the upper surface; C, dense short cilia on the margin of the lower surface. Scale bars: A, $1 \mathrm{~cm}$; B, C, $1 \mathrm{~mm}$.

\section{Pycnidia}

Numerous, on the upper surface, black, $c .0 .1 \mathrm{~mm}$ in diameter.

\section{CHEMISTRY \\ Cortex \\ $\mathrm{K}+$ yellow.}

\section{Medulla}

$\mathrm{K}+$ yellow to red, $\mathrm{C}-, \mathrm{P}+$ orange red, containing atranorin and salazinic acid (detected by TLC).

NOTES

This species can be separated from all the other species in subgenus Everniastrum by the presence of cilia on the 
upper surface, the thick and wide lobes (up to $5 \mathrm{~mm}$ wide) and the dense short cilia on the margin of the lobes. It might be mistaken for $H$. sinensis because of its rugose upper surface, but the latter species has a bare lower surface and sparse simple cilia on the margin; furthermore, $H$. sinensis has lobules on the upper surface. $H$. nepalensis, when exhibiting dense rhizines, might be confused with this species, but $H$. nepalensis has simple and sparse marginal cilia, and the upper surface is smooth without cilia. H. rhizodendroidea, having branched marginal cilia, is similar to this new species, but it has fruticose, irregularly branched cilia and a sparsely rhizinate lower surface.

15. Hypotrachyna vexans (Zahlbr. ex W.L.Culb. \& C.F.Culb.) Divakar, A.Crespo, Sipman, Elix \& Lumbsch

Phytotaxa 132 (1): 33 (2013).

Selected specimens examined. - China, Taiwan Prov., Alishan Mt, Kainoodai; 26.XII.1925; Asahina 79 (holo-, W[W]). Jiayi Co., Alishan Forest Park; 2330.653’N, 12048.984’E; 2307 m, on decaying bark; 26.IX.2015; L. S. Wang 15-49391. Taizhong Ci., Shaolaishan Mt; $24^{\circ} 15^{\prime} \mathrm{N}, 121^{\circ} 58^{\prime} \mathrm{E}$; $2300 \mathrm{~m}$, on bark; 25.IV.2007; CK Lin L4483, L4511. Yunnan Prov., Tengchong Co., Houqiao Vil.; $25^{\circ} 11.075^{\prime} \mathrm{N}, 98^{\circ} 19.906^{\prime} \mathrm{E} ; 1910 \mathrm{~m}$, on bark; 28.III.2012; L. S. Wang 12-33385. Pu'er Ci., Caiyanghe Forest Reserve; $22^{\circ} 35^{\prime} 59.17^{\prime \prime} \mathrm{N}, 101^{\circ} 07^{\prime} 01.19^{\prime \prime E}$; $1688 \mathrm{~m}$, on bark; 29.IV.2012; L. S. Wang 12-33803.

\section{NoTES}

For a detailed description, see Culberson \& Culberson (1981).

This species is characterized by a sparsely to densely isidiate upper surface, and the isidia are usually short or granulose (Fig. 5D), lacking rhizines on the lower surface and having sparse marginal cilia. $H$. fragilis also has isidia on the upper surface but differs by its long and fragile isidia (up to $3 \mathrm{~mm}$ long), usually coralloid-branched, and lobes that are wide and short, usually flat and appressed. In contrast, in $H$. vexans, the lobes are long and usually involute, and the lobe tips mostly curve downward. $H$. subvexans, with similar isidia, can be distinguished by the absence of salazinic acid in the thallus (medulla $\mathrm{K}-$ ) and wide lobes up to $3 \mathrm{~mm}$ wide.

\section{DISCUSSION}

\section{SPECIES DELIMITATION OF EVERNIASTRUM}

After examination of type specimens and the original descriptions, we found that delimitations of species are not always clear in Hypotrachyna subg. Everniastrum, e.g. as in the case of $H$. cirrhata and $H$. sorocheila, due to their very short original descriptions, small type specimens, and lack of DNA data. Furthermore, morphological characters for distinguishing species are usually very limited, as in the case of the type species $H$. cirrhata: species with a bare lower surface, simple cilia and no soredia or isidia are usually identified as $H$. cirrhata worldwide. However, phylogenetic analysis showed that they are not monophyletic (Fig. 1). A recent study (Kirika et al. 2016) discovered the same situation in another species, $H$. sorocheila.
This suggests that there are cryptic species hidden under these names and that the species diversity is higher than presently assumed. In this study, specimens from type localities were freshly collected and sequenced for $H$. cirrhata, $H$. nepalensis and $H$. vexans, providing a phylogenetic foundation for the delimitation of these species.

\section{Species Diversity in the Hengduan Mts}

The four new species described in this study have unique taxonomic, chemical and geographical characters and are supported by phylogenetic analysis with high support values. However, due to the lack of fresh specimens, there are still some groups of species with special morphological characters but without support from phylogenetic data awaiting confirmation. More floristic surveys are needed for further study: sampling of different populations of the same species and sampling of fresh, reliably identified material of described species to clarify their phylogenetic relationships. Although the subgenus Everniastrum has already received considerable attention in China, new species are still being discovered, showing the high species diversity of lichens in the Hengduan Mts area.

The discovery of four new species and a new floristic record for a species in this well-studied subgenus suggests that there are more cryptic species hidden within Everniastrum. Further studies are needed, involving more specimens and sequences from all over the world, especially from the type localities, to identify the proper species boundaries of this subgenus and to discover the species hidden under the traditional species names.

\section{Acknowledgements}

We would like to express our deepest gratitude to Ms Hong Deng from Herbarium Mycologium, Institute of Microbiology (HMAS); Dr Seppo Huhtinen from the Herbarium of the University of Turku (TUR); Dr Rusty Russell from the United States National Herbarium, Smithsonian Institution (US); and Dr Christian Bräuchler from the Vienna Museum of Natural History (W) for the loan of type and other related specimens.

This study was supported by grants from the Flora Lichenum Sinicorum (31750001), Youth Innovation Promotion Association (CAS), National Natural Science Foundation of China (Nos 31970022, 31670028, 31170023), Biological Resources Programme, Chinese Academy of Sciences (KFJBRP-017-23), and Second Tibetan Plateau Scientific Expedition and Research Program (STEP) (2019QZKK0503).

\section{REFERENCES}

ARUP U. 2002. - PCR Techniques and Automated Sequencing in Lichens, in Kranner I., BecketT R. P. \& VARMa A. K. (eds), Protocols in Lichenology: Culturing, Biochemistry, Ecophysiology and Use in Biomonitoring. Springer-Verlag, Berlin, Heidelberg: 392-411. https://doi.org/10.1007/978-3-642-56359-1_24

Chen J. B. 2011. - Parmeliaceae (Ascomycota) lichens in China's mainland VI. Eight species new to China in parmelioid lichens. Mycosystema 30: 881-888.

Chen J. B., WAng S. L. \& Xu L. 2015. — Flora Lichenum Sinicorum Vol. 4 Parmeliaceae (1). Science Press, Beijing: 55-66. 
Chen J. B., Wu J. N. \& WeI J. C. 1989. — Lichens of Shennongjia, in CHEN J. B., WU J. N. \& WeI J. C. (eds), Fungi and Lichens of Shennongiia. World Publishing Corp., Beijing: 386-493.

Culberson W. L. \& Culberson C. F. 1981. - The genera Cetrariastrum and Concamerella (Parmeliaceae): a chemosynthetic synopsis. The Bryologist 84: 273-314. https://doi.org/10.2307/3242843

Divakar P. K., Crespo A., Núnez-Zapata J., Flakus A., SipMAN H. J. M., Elix J. A. \& LumbSCH H. T. 2013. — A molecular perspective on generic concepts in the Hypotrachyna clade (Parmeliaceae, Ascomycota). Phytotaxa 132 (1): 21-38. https://doi. org/10.11646/phytotaxa.132.1.2

EgAN R. S. 1978. - A new Mexican species in the lichen genus Everniastrum Hale (Parmeliaceae). Mycotaxon 7: 55-57.

EKMAN S. 1999. - PCR optimization and trouble shooting with special reference to the amplification of ribosomal DNA in lichenized fungi. Lichenologist 31: 517-531. https://doi. org/10.1006/lich.1999.0226

Flakus A., Oset M., JabŁońska A., SaAvedra P. R. \& KuKWa M. 2011. - Contribution to the knowledge of the lichen biota of Bolivia. 3. Polish Botanical Journal 56 (2): 159-183. https:// doi.org/10.2478/pbj-2014-0020

Fries E. 1825. - Systema Orbis Vegetabilis. Primas lineas novae constrictionis periclitatur Elias Fries. Pars I. Plantae homonemeae. Lundae, Paris: 283.

GARDES M. \& BRUNS T. D. 1993. - ITS primers with enhanced specificity for basidiomycetes. Application for the identification of mycorrhizae and rusts. Molecular Ecology 2: 113-118. https:// doi.org/10.1111/j.1365-294X.1993.tb00005.x

Hale M. E. 1976. - Synopsis of a new lichen genus Everniastrum Hale (Parmeliaceae). Mycotaxon 3: 345-353.

Hale M. E. \& WirTh M. 1971. - Notes on Parmelia subgenus Everniiformes with descriptions of six new species. Phytologia 22: 36-40.

Hue A. M. 1898. - Causerie sur les Parmelia. Journal de Botanique 12: $177-189$.

JiANG Y. M. \& WEI J. C. 1989. — A preliminary study on Everniastrum from China. Acta Byrolichenologica Asiatica 1 (1-2): 43-52.

JiANG Y. M. \& WEI J. C. 1993. - A new species of Everniastrum containing diffractaic acid. Lichenologist 25 (1): 57-60. https:// doi.org/10.1006/lich.1993.1013

KatOH K., Kuma K., TOH H. \& MiYaTA T. 2005. — MAFFT version 5: improvement in accuracy of multiple sequence alignment. Nucleic Acids Research 33: 511-518. https://doi.org/10.1093/nar/gki198
Kirika P. M., Divakar P. K., Crespo A., Gatheri G. W., Mugambi G., LeavitT S. D., Moncada B. \& Lumbsch H. T. 2016. Molecular data show that Hypotrachyna sorocheila (Parmeliaceae) is not monophyletic. The Bryologist 119 (2): 172-180. https:// doi.org/10.1639/0007-2745-119.2.172

Orange A., James P. W. \& White F. J. 2001. — Microchemical Methods for the Identification of Lichens. British Lichen Society, London: 1-101.

POSADA D. 2008. - jModelTest: phylogenetic model averaging. Molecular Biology and Evolution 25 (7): 1253-1256. https://doi. org $/ 10.1093 / \mathrm{molbev} / \mathrm{msn} 083$

Rambaut A. 2012. - FigTree, v. 1.4.0. Institute of Evolutionary Biology, University of Edinburgh, Edinburgh. Available at: http:// tree.bio.ed.ac.uk/software/figtree/

RonQuist F. \& HuelsenbeCK J. P. 2003. - MrBayes 3: Bayesian phylogenetic inference under mixed models. Bioinformatics 19: 1572-1574. https://doi.org/10.1093/bioinformatics/btg180x

Sipman H. J. M. 1980. — Studies on Colombian Cryptogams X. The genus Everniastrum Hale and related taxa (Lichenes). Proceed. Kon. Ned. Akad. Wetensch. ser. C 83: 333-354.

SipMAN H. J. M. 1986. - Notes on the genus Everniastrum (Parmeliaceae). Mycotaxon 26: 235-251.

STAMATAKIS A. 2006. - RAxML-VI-HPC: Maximum likelihoodbased phylogenetic analyses with thousands of taxa and mixed models. Bioinformatics 22: 2688-2690. https://doi.org/10.1093/ bioinformatics/btl446

TALAVERA G. \& CASTRESANA J. 2007. — Improvement of phylogenies after removing divergent and ambiguously aligned blocks from protein sequence alignments. Systematic Biology 56: 564577. https://doi.org/10.1080/10635150701472164

WeI J. C. \& JIANG Y. M. 1982. — New materials for lichen flora from Xizang. Acta Phytotaxonomica Sinica 20 (4): 496-501.

White F. J. \& JAMES P. W. 1985. — A revised guide to the microchemical techniques for the identification of lichen substances. British Lichen Society Bulletin 57: 1-41.

White T. J., Bruns T. D., LeE S. \& TaYlor J. 1990. - Amplification and direct sequencing of fungal ribosomal DNA genes for phylogenetics, in INNIS M. A., GELFAND D. H., SNINSKY J. J. \& WHITE T. J. (eds), PCR Protocols: a Guide to Methods and Applications. Academic Press, San Diego: 315-321. https:// doi.org/10.1016/B978-0-12-372180-8.50042-1

ZAHLBRUCKNER A. 1930. — Catalogus Lichenum Universalis. Vol. VI. Borntraeger, Leipzig. 